\title{
Displacement and dispossession: redefining forced displacement and identifying when forced displacement becomes pillage under international humanitarian law
}

\author{
Kerrin Geoffrey Buck
}

\begin{abstract}
Conflict-induced migration is arguably the most urgent humanitarian challenge today. A growing number of people are forced from their homes each year. The dispossession of civilians by armed parties, furthermore, through forced displacement has become a prevalent phenomenon. This article seeks to provide clarity to civilians, humanitarians, and other stakeholders, attempting to reduce civilian vulnerability to forced displacement through the application of international humanitarian law (IHL). While $\mathrm{IHL}$ prohibits forced displacement, pillage, and illegal appropriation, a number of problems arise when we try to implement these laws in practice. Establishing the illegality of an act of forced displacement, for example, may require legal analysis on a case-by-case basis. Furthermore, whether appropriation by force due to military necessity is legal or illegal is unclear due to a divergence between $\mathrm{HL}$ treaty provisions and customary international humanitarian law $(\mathrm{CIHL})$. In addition, when forced displacement becomes illegal, appropriation or pillage is not defined. This paper views these problems from a Humanitarian Protection perspective. The objective of the article is to provide practical criteria for stakeholders aiming to apply the law in protection of civilians and their property.
\end{abstract}

Keywords: International humanitarian law, Forced displacement, Pillage, Illegal appropriation

\section{Introduction}

It will suffice to mention that millions of human beings were torn from their homes, separated from their families (...) among whom there were a great many women, children, old people and sick, (...) thankfulness for the prohibition embodied in this paragraph, which is intended to forbid such hateful practices for all time (ICRC 1958 Commentaries Art 49) (GC VI 1949).

The objective of this paper is to define international humanitarian law (IHL) which can be applied to reduce civilian vulnerability to forced displacement and illegal appropriation or pillage through displacement. The paper will, therefore, clarify the illegality of forced displacement

\section{Correspondence: kerrinbuck@gmail.com}

University College Dublin, Ballinatone, Greenan, Rathdrum, Co. Wicklow, Ireland 
These opening passages provide a synopsis of the overall content and objectives of this paper. The following sections of this introduction will provide a more in-depth synopsis of the article.

\section{The practical application of law from a humanitarian perspective}

The subject of this article is the law; however, it is written not from a legal perspective but from a humanitarian perspective. The following section will, therefore, differentiate between a legal perspective and humanitarian perspective on IHL.

Architects through practical application of laws, standards, and regulations design and manage the construction of secure safe buildings for people. Humanitarians endeavour through principles, laws, standards, and regulations to provide assistance and protection to people in need, during disaster, emergency, and conflict.

This study concerns the practical application of the law in achieving an objective, not in establishing guilt or innocence ex post facto. This is important to understand, as for example, a judge, by consulting specific legal provisions and applying the law ex post facto, may be able to rule that an architect did not construct a building legally. The same judge may have great difficulty, however, applying those same architectural regulations and laws to build a safe and secure building. A judge, furthermore, may not be considered qualified to do so. Premised on this logic, we can infer therefore, that an architect is responsible for the application of the law during construction. In practical terms, architects are the professional incumbents of the laws that govern construction. They hold, in effect, an office responsible for ensuring that a building is constructed in accordance with the law.

Equivalently, humanitarians are the professional incumbents of the laws that regulate the protection and assistance of people during conflict and emergency. Again, a judge may establish if an act during conflict or disaster was illegal ex post facto, by referencing legal provisions and providing evidence of their violation. There may be a defence and a prosecution furthermore, neither of whom have the professional responsibility of providing protection and assistance to people during humanitarian crisis. Conversely, however, humanitarians have the responsibility for the practical application of the law, in pursuit of the objective of providing protection to people during conflict and emergency.

Therefore, while architects and humanitarians are not responsible for the enforcement of the law, they have the professional capacity to establish when laws are not being adhered to and to take action accordingly. In the case of an architect, this may mean halting construction, until a contractor meets the regulatory structural standards set by an engineer or assisting a client to take legal action against a contractor. In the case of a humanitarian, this may mean temporarily suspending operations, if parties are diverting aid, and denying access to vulnerable populations.

An architect, in addition, can be consulted to explain what the consequences might be of an illegally constructed building having inadequate foundations, e.g. the entire building collapses crushing its residents. A humanitarian might be consulted to explain, what would happen if conflict parties engage in crimes against humanity, such as the widespread and systematic illegal appropriation of civilian property through forced displacement, e.g. collapse of the economy, failure of agricultural production, mass displacement, famine, and humanitarian crisis.

This section has differentiated between the enforcement of the law from a legal perspective and the practical application of the law from a humanitarian perspective, introducing, thereby, how this article concerns the practical application of the law in the present during conflict and emergency.

\section{The legality of forced displacement from a humanitarian perspective}

The subsequent part of this introduction summarizes why a humanitarian perspective on IHL is required if civilian vulnerability to forced displacement and illegal appropriation through forced displacement is to be reduced. Furthermore, the section presents the argument that the current perspective on IHL may even increase vulnerability to forced displacement and illegal appropriation and provides only limited protection to civilians and their housing, land and property (HLP).

This research analysis will bring to light that differentiating between a legal and a humanitarian perspective is vital, if we hope to reduce civilian vulnerability to forced displacement through IHL. Pertinent is that a number of transitional justice scholars take the position that in order to establish the criminality of an act of forced displacement, an analysis of the conflict as it was at the time the displacement took place must be carried out (Bradley 2013; Andreu-Guzmán 2013; ICTJ Research Unit 2012). Human rights law scholars such as Cantor (2012), in addition, contend that due to the exceptions of 'imperative military reasons' or 'civilian security', establishing the illegality of forced displacement must take place on a case-by-case basis. In contrast, a number of criminal and international law experts, however, hold that forced displacement is always a crime and that the burden of proof that an exception is valid lies with the accused (Hayashi 2010; Jacques 2012; Olásolo 2013; Korner 2012; Willms 2009). The former arguments take the position that forced displacement is not in itself 
illegal, and the latter takes the position that forced displacement is illegal unless it can be proven that an exception of 'imperative military reasons' or 'civilian security' applies. These positions are based on a legal $e x$ post facto analysis and are regrettably of little assistance to humanitarians attempting to apply the law to reduce civilian vulnerability in the field. Hayashi (2010 p 130) brings to light this protection gap by highlighting '(...) the potential use (...) of military necessity not only as an exception but also as a grounds for excluding criminal responsibility'.

The immediate problems that this causes for civilians themselves, humanitarians, or other protection actors, attempting to apply the law in practice, to reduce civilian vulnerability to forced displacement, is self-explanatory. As if the criminality of a particular act can only be adjudged after the fact, and there are possible grounds for excluding criminal responsibility, then how can we deter perpetration of the act in the present? If there is, moreover, a current perception that military necessity excludes forced displacement as a crime, especially in the current climate of counter-terrorism, legal ambiguity may even encourage its practice (VDC 2015). It is important to recognize, furthermore, that it is those responsible for 'ordering' forced displacement, not those at risk, or those enforcing the law, or even Humanitarians, who decide if a forced displacement is justified, for imperative military reasons or civilian security in real time. A number of scholars recognize the legal obstacles stakeholders face when attempting to reduce civilian vulnerability to illegal forced displacement (Zapater 2010; Andreu-Guzmán 2013 et al).

There is, in addition, the practical question of how we can prevent HLP from being appropriated illegally, if the act employed by the perpetrators is justifiable as an exception. If for example HLP from which civilians have been displaced is appropriated or occupied, can an act of forced displacement be considered illegal appropriation or pillage if an exception applies? In addition, even if a displacement is clearly illegal and civilian HLP is appropriated or occupied, at what point can this act be considered to have become illegal appropriation or pillage? Moreover, the difficulties of reclaiming property, or seeking justice for an act of forced displacement in the context of transitional justice and peace agreements, further complicates civilian protection (Andreu-Guzmán 2013; Sassòli 2010; Paglione 2008; Leaning 2011; Korner 2012).

The objective of this section was to highlight that while the subject of this paper is the law, it is not aimed at the legal profession to assist in defining criminality ex post facto. It is written rather to assist in the practical application of the law, in real time in the field of Humanitarian Action. This paper, therefore, is written for humanitarians, protection actors, civilians themselves, and all other stakeholders, who wish to reduce civilian vulnerability to illegal forced displacement and illegal appropriation through displacement.

\section{Establishing the illegality of an act of forced displacement and pillage/illegal appropriation through forced displacement}

The following paragraphs introduce how this article aims to provide clear IHL criteria that can be applied by stakeholders to reduce civilian vulnerability to forced displacement. In addition, the section provides a synopsis of a central argument of this paper, which maintains that all stakeholders can establish, and act, if illegal forced displacement or illegal appropriation through displacement takes place.

This paper focuses directly on violations of International Law in the nexus between forced displacement, pillage, and illegal appropriation. The objective of this paper is to clarify when forced displacement is illegal and when it becomes pillage or illegal appropriation under IHL. A comparative analysis is carried out of contemporarily applicable IHL treaties and customary international humanitarian law (CIHL). For the purposes of this study, CIHL is considered to be encompassed by the ICRC [1995] studies of CIHL, the case law of the ad hoc tribunals, and the ICC. The objective of the analysis is to provide stakeholders with clear legal criteria for application to reduce civilian vulnerability to illegal forced displacement and illegal appropriation or pillage through displacement.

Currently, the authority to decide if an act of forced displacement is illegal lies either with a United Nations (UN) Special Commission, a UN Special Rapporteur, an agreed or mandated humanitarian organization, or with a national, international or third party state judiciary (Bongard and Somer 2011; Schrepfer 2012; UNSC 2004; ICRC 1958; GC VI 1949; ICID 2004). In addition, the high contracting parties to conflict can appoint a neutral third party state, or in certain circumstances a neutral humanitarian organization such as the ICRC, as protecting power. Subsequently, the appointed party can assess if the legal criteria of a forced displacement has been fulfilled [GC IV Arts 9 \& 11 1946; GC IV Arts 9 \& 11 commentaries 1958] (GC VI 1949). In the event, nonetheless, that a forced displacement is deemed to be illegal, those responsible must ultimately face criminal justice measures and be proven guilty in a court of law (Andreu-Guzmán 2013 et al).

This article argues that while most stakeholders cannot assign guilt or enforce the law they can establish if a forced displacement is illegal and when forced displacement becomes pillage or illegal appropriation. This paper takes the position, that ultimately, all stakeholders can decide if the criteria of a legal forced displacement or 
evacuation has been transgressed and if the HLP of civilians is being pillaged or illegally appropriated.

Therefore, the objective of this article is, as the previous paragraphs have summarized, to provide legal criteria not to establish guilt ex post facto but to be applied actively in the field to reduce civilian vulnerability.

\section{Ordering forced displacement}

The following passages will introduce a central issue of this article which is the ordering of forced displacement. To assist protection actors in the field, this paper will seek to establish, who the individuals are that are responsible, under international criminal and humanitarian law (ICHL), for ensuring that illegal displacements do not take place.

A number of binding IHL provisions employ the passage: 'Ordering the displacement of the civilian population (...)'. On closer examination, however, exactly what is implied by the term 'ordering' becomes unclear. For example, does 'ordering' mean any action by a capable actor which leads to forced displacement, such as planning, instigation or incitement? If this is not the case, then must every order constitute a strictly construed directive issued to subordinate combatants by their highest office of military command? Do these IHL provisions, furthermore, imply that the existence of an order is a requisite necessity of incurring criminal responsibility for forced displacement?

These questions and others, which are central to this paper, are answered through the ICHL research of the $E l$ Rosario International Law Clinic carried out for the International Criminal Courts' (ICCs')-Office of Public Council for Victims (OPCV) (Olásolo et al. 2016). Furthermore, through the research of the International Law Clinic, we establish criteria that those 'ordering' forced displacement need to fulfil under ICHL.

The objective is to provide clarity for protection actors, and all stakeholders, as to who is responsible under ICHL for the 'ordering' of illegal forced displacement. It is also important for protection actors to understand developments in ICHL, which increase the obligations or rights of stakeholders, for example, in the criminal treatment of perpetration and participation, in relation to joint criminal enterprise (JCE) and command responsibility (Olásolo 2013; Olásolo et al. 2016; Cassese et al. 2013).

The previous paragraphs provide an introduction to the question of 'ordering' forced displacement. Through the IHL research analysis of this paper, we will show that the issue of ordering is central to reducing civilian vulnerability to forced displacement and illegal appropriation through forced displacement.

\section{Applying international humanitarian law, international human rights law, and national law}

This section introduces why IHL has been chosen as the main vehicle of the article. An assessment will be made in the following paragraphs of the applicability of IHRL and national law to reducing civilian vulnerability to forced displacement and pillage.

IHL will provide the main vehicle of this paper, as it regulates the actions of armed parties in both international armed conflict (IAC) and non-international armed conflict (NIAC). The levels of protection, nonetheless, that international human rights law (IHRL), national law, and other bodies of law can provide from forced displacement during conflict should not be dismissed. To the contrary, for example, if a NIAC exists within a state but the incumbent regime refuses to recognize an armed non-state actor (ANSA) party to the conflict, IHRL and national law may provide the only legal protection for civilians against forced displacement. This article, therefore, underlines the importance of considering all applicable bodies of law which may reduce civilian vulnerability to forced displacement (Schrepfer 2012; ICRC 2013; Jong 2015; Lane 2016).

There are numerous existing legal vehicles through which stakeholders can encourage conflict parties to commit to reducing civilian vulnerability, e.g. unilateral declarations or special agreements (Mack and Pejic 2008; Lacroix et al. 2011; Jong 2015). Numerous documents created during conflict highlight that these legal mechanisms provide parties, particularly ANSAs, with vehicles for making contractual commitments to civilian protection (Heffes and Kotlik 2014; Sassòli 2010; Rondeau 2011). This paper aims to provide criteria that will guide protection actors and can be adopted in contracts with conflict parties to reduce civilian vulnerability to forced displacement and HLP pillage.

With regard to IHRL and this paper, consider that a number of provisions might be included in contracts between parties and other stakeholders during conflict from, e.g. the Universal Declaration of Human Rights (UDHR), the International Covenant on Civil and Political Rights (ICCPR) and the International Covenant on Economic, Social and Cultural Rights (ICESCR). The aim should be to strengthen and clarify legal criteria which protect civilian property, whether public or private, from being illegally appropriated through displacement (Lane 2016; Leckie and Huggins 2011; Golay and Cismas 2010). Suitable provisions might include UDHR (1948) Art 17. '(1) Everyone has the right to own property alone as well as in association with others. (2) No one shall be arbitrarily deprived of his property'. It may be important, moreover, to include IHRL provisions which provide protection from resource pillage, which is often the root cause of conflict induced migration. 
ICCPR [1966] \& ICESCR [1954] Art 1 (2), common to both treaties for example states that 'All peoples may, for their own ends, freely dispose of their natural wealth and resources without prejudice to any obligations arising out of international economic co-operation, based upon the principle of mutual benefit, and international law. In no case may a people be deprived of its own means of subsistence'.

It is important to be aware, nonetheless, that many of the IHRL provisions which can protect civilians from forced displacement or illegal appropriation through displacement, such as ICCPR [1966] Art 12. (1) and ICCPR [1954] Art. 17. (1) can be derogated from during armed conflict [ICCPR Art 4 1976]. Nevertheless, the advantage of adopting IHRL provisions in special agreements such as ceasefire or peace agreements, which may signal the end of a conflict, is that unlike IHL, IHRL remains applicable once the conflict has ended (Mack and Pejic 2008).

While the central focus of this paper is IHL, it is vital to understand the extent to which national legal systems can provide protection to civilians from forced displacement or illegal appropriation during conflict. Research brings to light that many states retain the right to displace their citizens by force; this can be seen in the legislation and military manuals of numerous countries (Bernard et al. 2011a, b). Numerous studies highlight that incumbent regimes often create or retain legislation which ensures their hegemony over natural resources in conflict with IHL or IHRL. This legislation facilitates JCE and allows markets for illegally appropriated HLP to develop or flourish. The reluctance or inability of incumbent regimes, furthermore, to legislate in protection of HLP rights or provide secure title or tenure registration systems exposes civilians to dispossession (Leckie and Huggins 2011). The inability of IDPs, in addition, to provide documentary evidence of being legally present on HLP they inhabited, enables authorities to deny basic rights of populations during displacement (Personal Interview 2014a, 2014b).

It is important to recognize, nevertheless, that many countries have engaged in the process of bringing their jurisprudence, criminal justice systems, and judicial proceedings in line with international law. Research highlights that states have begun prosecuting their own citizens as perpetrators of acts of forced displacement under legislation in accordance with IHL (Personal Interview 2014a, 2014b). Since 2002, the ICC has provided complementary support to numerous states to during the alignment of their jurisprudence with the Rome Statute (RS) (Seils 2016; Philippe 2006). Research indicates the majority of states have provided universal jurisdiction over international crimes within their national courts; however, the extent to which IHL is adopted into national law varies greatly (Amnesty 2012; Philippe 2008; IJRC 2016; ICJ 1945). Nevertheless victims, for example, of pillage or forced displacement have the possibility of seeking justice in another national jurisdiction (Schrepfer 2012; Mulvey 2013; Andersen 2011; Roht-Arriaza 2001). A case in point is the judgement by the District Court of Jerusalem who found Adolf Eichmann guilty of deportation for acts of internal displacement [Attorney General v. Adolf Eichmann 1961 Criminal Case No. 40/61].

This section provides an explanation of why IHL is the body of law chosen for this paper. How IHRL might complement IHL in special agreements, in addition, is introduced. Finally, the section describes some of the issues humanitarians may encounter while attempting to apply national law to reduce civilian vulnerability to forced displacement and HLP pillage.

\section{Methodology}

This chapter provides an overview of the methods employed during the research, analysis, and drafting of this paper. The majority of the article constitutes the result of individual research methods employed by the author. However, the paper includes team research carried out while the author was a member of the $E l$ Rosario International Law Clinic; this research was carried out through a variety of methods which are summarized below (Olásolo et al. 2016).

\section{Observation}

This article analyses how IHL applies to a pattern of abuse that the author of this paper has observed, researched, and provided humanitarian protection against in conflicts including: the Former Yugoslavia 1993-1994, Angola 1998-1999, Colombia 2014-2015, and South Sudan 2016-2017.

\section{Independent research}

The scope and extent of HLP theft perpetrated by armed parties through forced displacement was identified by the author through literature review and qualitative research methods (Personal Interview 2014a, 2014b; Engel and Ibáñez 2007). The majority of this paper, however, consists of a legal research analysis. Therefore, the relevant provisions from international instruments of IHL have been analysed, compared, and questioned in relation to how they encompass the identified pattern of abuse. The origins, drafting and commentaries of each applicable article has been examined. The legal application of these provisions, furthermore, has been examined for consistency through the case law of the ICC and the ad hoc tribunals. In addition, the research of numerous scholars has been analysed and referenced on key issues throughout the paper. Ultimately, the legal analysis of this 
paper aims to provide answers to a pattern of abuse identified through literature review, analysis of existing research, and the authors' own research.

\section{Group research}

The author was a member of the 2014 El Rosario University International Law Clinic, which carried out research for the 'Office of Public Council for Victims' (OPCV) of the International Criminal Court (ICC) and the Justice and Peace Tribunal (JPT) in Bogota, Colombia. The objective of the Clinic was to answer a legal question posed by the OPCV and to carry out complementary research for magistrates of the JPT. The ICC research regards the ordering of forced displacement and forms a central part of the legal analysis of this paper. The research team systematically investigated issues related to the ordering of forced displacement, such as proportionality, civilian security, military necessity, and command responsibility.

The El Rosario team was divided into groups to carry out in-depth research into international jurisprudence, case law, and ICHL. The research method in general can be described as the Issue, Rule, Analysis and Conclusion (IRAC) case study approach. Through this method, researchers take a legal issue for consideration, such as forced displacement, and consider it in a number of different scenarios. Each research group, thereby, analysed relevant issues systematically and drew conclusions. The research was carried out through the following methods:

Focus groups-Weekly focus groups were held to discuss the research issues, which included the concepts of: military necessity, civilian safety, proportionality, omission, duress, joint criminal enterprise, and command responsibility. Team members researched relevant issues, through analysis of the case law of the ad hoc tribunals, and the complementary legal process in Colombia. The objective was to analyse various contributing issues that combined would answer the question posed by the ICC, which is the central subject of this paper.

Combined research-Groups or pairs carried out research into one aspect of the topic for discussion in the coming week. If for example, your group had military necessity, you and your partner might research proportionality, discuss the issue with your group, and then give a presentation to the research team.

Individual research-The magistrates of the JPT requested that specific research was carried out on separate issues, and accordingly, a number of reports were written. This research included the examination of over 60 recent recorded cases against paramilitary actors. The relevant reports on subjects including HLP restitution of victims of crimes against humanity have also been analysed in this paper.

Interviews with authorities-Weekly meetings were held with magistrates to discuss subjects, such as forced displacement, complementarity, HLP reparation, transitional justice, reconciliation, and repatriation (Personal Interview 2014a, 2014b; Olásolo et al. 2016).

\section{International humanitarian law research analysis}

The Geneva Conventions of 1949 are paramount in this regard, providing in unmistakable terms for universal jurisdiction over grave breaches of those Conventions. International crimes were no longer to remain unpunished (Philippe 2006).

This chapter begins with a general synopsis of how this research analysis seeks to define IHL which can provide universal protection to civilians from forced displacement and illegal appropriation through forced displacement. Then, the chapter goes on to provide a legal research analysis which progresses by delineating and analysing sequentially the issues raised in the introduction. The objective ultimately is to define IHL which can be applied to reduce civilian vulnerability to forced displacement and illegal appropriation or pillage through displacement.

The first section underlines that without military engagement or legitimate threats to civilian security, stakeholders cannot consider forced displacements during conflict to be legitimate. The following section goes on to analyse when forced displacements can be considered as legal under the 'exceptions'. Subsequently, research is analysed from the El Rosario International Law Clinic into the command responsibilities of those 'ordering' evacuation, the act of ordering is defined, and criteria of a legal order of forced displacement is provided. The chapter proceeds to clarify when forced displacement becomes pillage or illegal appropriation. The penultimate section addresses ambiguity regarding the definition of the crime of pillage. The final segment answers if appropriation by force from civilians is prohibited without exception under IHL.

\section{Defining IHL that can provide universal protection to civilians from forced displacement and illegal appropriation through forced displacement}

The Geneva Conventions of 1949 are paramount in this regard, providing in unmistakable terms for universal jurisdiction over grave breaches of those Conventions. (Philippe 2006 p378). 
The objective of this analysis is to provide findings that may form the basis of provisions, which can provide universal legal protection for civilians from forced displacement and illegal appropriation through forced displacement. This section outlines how some IHL treaty's provisions are and others become universally binding through customary law.

The findings of this research analysis are founded on legal sources which can provide universal protection (Henckaerts 2010). The Geneva Conventions (GCs) of 1949 are ratified by all states are therefore universally binding. The application in practice of the provisions of the GCs, furthermore, can provide a powerful source of customary law. GC IV Art 49 for example was drafted to apply to IAC; however, it provides a customary definition of a legal forced displacement which is applicable in NIAC or IAC. This is because the International Criminal Tribunal for the former Yugoslavia (ICTY) created international legal precedence by applying GC IV Art 49 to define a legal evacuation or transfer [Naletilić $\mathcal{E}$ Martinović ICTY IT-98-34; ICTY 2009]. This research analysis has examined the intention, origins, drafting, and commentaries of each of the relevant IHL treaty provisions which relate to forced displacement, pillage, and illegal appropriation. Throughout this research analysis, moreover, CIHL is referenced from the relevant case law of the ad hoc tribunals and the ICC. Moreover, reference is made to the academic research of a number of recognized legal scholars, on contentious issues such as when appropriation by an armed party becomes illegal, and how pillage is defined as a crime.

This section has established why the legal sources which have been analysed in this paper where chosen. The preceding paragraphs, furthermore, have defined the sources of CIHL and legal scholarly research to be referenced.

\section{Military engagement or threats to civilian security}

In the succeeding paragraphs, we will examine, when forced displacement is clearly illegal, due to the absence of legitimate threat to civilian security, from military engagement or legitimate military operations.

Significant research carried out into the root causes of displacement clarifies that while military engagement may be the pretext, pillage, or illegal appropriation is frequently the real objective of civilian displacement (Le Bilion 2001; McGregor 2009; Reno 2009a, 2009b; Ballintine and Nitzschke 2003 et al.; Tripathi 2005). Extrapolation of information across numerous studies and conflict data sources, furthermore, establishes that pillage or illegal appropriation is a root cause of conflict-induced migration globally (Adhikari 2013; Engel and Ibáñez 2007; Maher 2015; ACLED 2015). An examination of current research brings to light that civilian objects are being targeted through a variety of direct or indirect displacement strategies by armed actors and their partners. This research, furthermore, brings to light that forced displacement is being used, in the context of an armed conflict, to commit pillage, and not to protect civilians from military operations (Ibid; Zapater 2010). Research reveals that frequently, there is a complete absence, furthermore, of actual military engagement which might endanger civilians (Bangerter 2011; Azam and Hoeffler 2002; Le Bilion 2001; McGregor 2009; Reno 2009a, 2009b).

A clear example of the inapplicability of imperative military reasons for evacuation is found in ICTY case Prosecutor v. Krstic [IT-98-33-T para 527], furthermore, that: 'In this case no military threat was present following the taking of Srebrenica. The atmosphere of terror in which the evacuation was conducted proves, conversely, that the transfer was carried out in furtherance of a well organized policy whose purpose was to expel the Bosnian Muslim population from the enclave. The evacuation was itself the goal and neither the protection of the civilians nor imperative military necessity justified the action'.

Following this research analysis, it is clear that under IHL, civilian displacement cannot be ordered for reasons related to the conflict, unless for imperative military reasons that involve the security of civilians. While 'imperative military reasons' will be defined in the following section, examination of binding sources of IHL clarifies that civilian displacement cannot be ordered as a strategy of conflict [GSs 1946; ICTY IT-98-33-T et al.].

Stakeholders therefore should be aware that if it cannot be proven that the security of civilians is threatened through military engagement or legitimate military operations, then any act that constitutes an order of evacuation/forced displacement cannot be considered legitimate.

This section has underlined that civilians and their property are frequency the actual target of armed parties. Furthermore, that all stakeholders should be aware that under IHL civilians cannot be forcibly displaced from their HLP, unless the circumstances of the conflict demand and the exceptions apply.

\section{Imperative military reasons and the security of civilians}

The following section will define when the exceptions of imperative military reasons and the security of civilians apply. Furthermore, the aim of this segment is to disprove the assumption that expert judicial investigations are required, ex post facto, to adjudge if a forced displacement/evacuation was illegal (ICTJ Research Unit 2012; Zapater 2010; Hayashi 2010; Zayas 1975).

There are established criteria in IHL, which must be fulfilled by those 'ordering', if a displacement is to be considered legal (Zayas 1975). Generally, the ICRC 
[2005] CIHL studies highlight that IHL progressively seeks to protect civilians and their property. There has been considerable historical debate, however, in relation to the exception of 'imperative military reasons'. Hayashi (2010), through a study of the commentaries of the GCs, finds that 'imperative military reasons' exist only when the presence of protected persons impedes imperative military operations. Therefore, civilian security must be at risk for an order of forced displacement, based on imperative military reasons, to be legitimate. The ICRC [1958 p278] (GC VI 1949) commentary on GC IV Art 49 states; '(...) evacuation may only be ordered in two cases (...) namely when the safety of the population or imperative military reasons so demand. If therefore an area is in danger as a result of military operations or is liable to be subjected to intense bombing, the Occupying Power has the right and (...), the duty of evacuating it partially or wholly, by placing the inhabitants in places of refuge. The same applies when the presence of protected persons in an area hampers military operations. Evacuation is only permitted in such cases, however, when overriding military considerations make it imperative; if it is not imperative, evacuation ceases to be legitimate'.

There is significant legal analysis from a number of legal scholars on the prosecution of forced displacement due to military necessity (Jacques 2012; Korner 2012; Hayashi 2010; Zayas 1975). A number of these authors highlight that legality of an evacuation order must be based on imperative military reasons and must be assessed in the light of the knowledge available to the military commander 'at that time'. This is irrespective of the fact that a subsequent examination may show an absence of imperative military reasons. Zayas (1975, p219) infers from the trials of General Lother Rendulic and Field Marshal Erich von Manstein that legal displacement refers to 'Situations where army commanders judge that the safety of the civilian population requires that they be removed from the battle zone and not when the same army commander decides that military advantage would be gained by removing the population and scorching the earth behind them'. The legality of carrying out an evacuation due to military necessity is based on the information available at that time to those ordering. The examination of that information by the judiciary has become known as the 'Rendulic test' [Prosecutor v.Prosecutor v. KrsticIT-9833-T para 526] (Merriam 2016).

Further analysis of the General Lothar Rendulics' trial highlights, however, that his acquittal for a scorched earth policy in Finmark, Norway, is based on the exception of military necessity based on the Hague Regulations (HR) [1907] Convention IV Art 23 (g): 'To destroy or seize the enemy's property, unless such destruction or seizure be imperatively demanded by the necessities of war' ['Opinion and Judgment of Military
Tribunal V," United States v. Wilhelm List, et al. 1948 p1296]. There has been significant progression in IHL on military necessity since the drafting of the HRs aimed at protecting civilians from scorched earth policies, which can be seen in AP I (1977) Art 54, for example.

Therefore, from a purely humanitarian perspective, we can assume that the evacuation that Rendulic 'ordered' would be considered illegal today, due to the destruction of civilian objects required by civilians to survive, and the illegal civilian displacement. The Tribunal, moreover, premised the logic of its acquittal based on the information available to them which supported that Rendulic was correct in his assumption that an armed opponent might sustain themselves on available civilian objects [ibid].

The ICRCs' [Henckaert \& Doswald-Beck 2015] study of CIHL holds that parties to a conflict must avoid any act of displacement caused by their own acts, particularly those caused by acts contrary to IHL. The ICRC [2005] CIHL study and RS Art. 7. 2. (d), further, forbids the use of coercive acts, direct, and indirect means, which may cause the displacement. GC IV Art. 49, nevertheless, is often referred to as the 'exception', as it allows for the evacuation of the population if imperative military reasons so demand. Considered in conjunction, AP I (1977) Arts 58(a) and (c), and GC IV Art 49, however, impose a duty on military commanders to evacuate civilians from the vicinity of military objectives that endanger the security of civilians (Jacques 2012). The ICRC [1987 p1471] commentary on AP I (1977) Art 17, furthermore, states that 'The situation should be scrutinized most carefully as the adjective 'imperative' reduces to a minimum cases in which displacement may be ordered'. Therefore, we must conclude that only those specific civilians who will be endangered by imperative military operations can be legitimately displaced.

Legal scholars concur that evacuation has a protective element which is absent from all forms of illegal displacement. The research of these scholars underlines that if evacuations/forced displacements do not fulfil adequate standards of civilian protection, then they must be seen as illegal (Jacques 2012; Zayas 1975). Further, based on an analysis of IHL treaty provisions and CIHL and in relation to the objective of this paper, an evacuation/forced displacement must therefore be considered illegal if ' $(. .$.$) satisfactory conditions (...)' are not pro-$ vided for the security of civilians by the armed party responsible. In addition, transfer, evacuation, or forced displacement can be considered illegal, if the protecting power (if designated) is not informed that an evacuation is taking place. Suggesting the existence of an obligation, on those responsible for ordering, to have an organized plan of evacuation/forced displacement and to provide that plan to a third party (e.g. the protecting power) concerned with the protection of civilians. Obviously, the need for 
secrecy during military operations may decide when such a plan may be shared; nevertheless, this does not diminish the obligations of, e.g. GCIV Art 49, AP II (1977) 17, and AP I (1977) 58.

This segment of the research analysis has defined when the exceptions of imperative military reasons and civilian security apply. In addition, the section has identified that stakeholders can establish if forced displacements are illegal if adequate standards of civilian protection are not fulfilled by those responsible for 'ordering'.

\section{'Ordering', who is responsible for illegal forced displacement?}

The following section examines the research of the $E l$ Rosario International Law Clinic into the ordering of forced displacement. Subsequently, the research analysis will examine the extent to which those in a position to 'order' are responsible for forced displacement.

Significantly, the International Criminal Court (ICC) began seeking their first ever conviction of illegal forced displacement in 2014, in the Bosco Ntaganda case. During, Pre-Trial Chamber II, the defence appealed against the decision confirming the charges: 'In the opinion of the Defence, the Elements of Crimes "are clear and unambiguous" in the sense that an order is required by the perpetrator of the crime'. The defence, thereby, alleging that the ICC had erroneously confirmed the charge of forced displacement '(...) in the absence of any order by the suspect to displace the civilian population' [ICC-01/ 04-02/06 para 31]. The defence, thereby, claimed that Mr Ntaganda could not be held responsible for unlawful displacement, as it could not be established that he had given the order. The prosecution challenged, subsequently, if it was necessary to prove that an order had been given for criminal responsibility to attach. The appeal, however, was rejected, on the grounds that the defence where merely expressing an opinion on a matter sub judice [ICC-01/04-02/06 para 31]. It raised an important question, nonetheless, one that may influence the case, the prosecution of forced displacement, and Humanitarian Action [ICC-01/04-02/06].

The question under debate asks if RS Art 8(2)(e)(viii) requires that the Prosecutor of ICC must prove that a specific order was given by the accused that led to illegal forced displacement. The following excerpt from the pre-trial chamber shows that evidence could be provided that Mr Ntaganda had played a role in inciting violations that included displacement and pillage. The issue for debate, however, is if it is necessary to prove that an actual direct order had been given to establish guilt. The following excerpt shows $\mathrm{Mr}$ Ntaganda in his capacity within the Union of Congolese Patriots (UPC)/Patriotic Forces for the Liberation of Congo (FPLC), inciting and giving instructions that call for forced displacement, pillage, and other violations to be committed. If a direct order was given, and who was responsible for the overall strategy, is however, unclear:

Mr. Ntaganda, in his official capacity within the UPC/ FPLC, regularly raised awareness among the troops and Hema civilians, in person or by radio, of the need to exterminate the Lendu and chase them away from the territory under the control of the UPC/FPLC, regardless of whether they were taking part in hostilities or not. The evidence further shows that when addressing UPC/FPLC troops at a military parade in Mabanga, in November 2002, Mr. Ntaganda used the expression "piga na kuchaji" or "kupiga na kuchaji", which meant that troops should fight and pillage everything, including "women". Another high-ranking official, Commander Salumu Mulenda ("Mr. Mulenda"), also employed this expression at a UPC/FPLC meeting in Lalo village, in preparation for the attack on Mongbwalu on or about 20 November 2002. The evidence further indicates that before attacking the town on or about 6 May 2003, the UPC/FPLC instructed the Hema civilian population to leave Bunia, as all remaining people would be considered to be the enemy [ICC-01/04-02/06].

The question under debate concerns humanitarians in a number of ways: firstly, when we consider stakeholder responsibility for, or complicity in, illegal forced displacement or dispossession through forced displacement; secondly, how we address the issue of forced displacement, and illegal appropriation through forced displacement as humanitarians; and finally, in establishing who has responsibility for carrying out a legal forced displacement or evacuation.

The El Rosario University International Law Clinic was asked to investigate the following question and a number of related questions by the 'Office of Public Council for Victims' (OPCV) of the ICC:

Regarding the chamber's rejection of the request for leave to appeal filed by the Defence in the Ntaganda case against the decision confirming the charges, does article $8(2)(\mathrm{e})$ (viii) of the Rome Statute require the Prosecutor to prove that a specific order was given by the perpetrator for the unlawful displacement of the civilian population? (...)

The provision in question is important for protection actors attempting to reduce civilian vulnerability to forced displacement and can be found in three sources of binding international law: (i) AP II (1977) Art 17; (ii) RS Art 8(2)(e)(viii); and (iii) ICRCs study on CIHL Rule 129 (B). All three sources contain the following provision: 
Ordering the displacement of the civilian population for reasons related to the conflict, unless the security of the civilians involved or imperative military reasons so demand.

An initial study of legal theory and international law by the research team found that if the intention is to displace is unlawfully acted upon criminal liability immediately attaches. In this case, the intention is enacted through an 'order'. Therefore, under RS Art 8(2)(e)(viii), an order whether the displacement is carried out or not constitutes a punishable preparatory act.

The International Law Clinic team, however, highlighted a number of subjective elements we should consider in relation to the ordering of forced displacement and in establishing who is responsible for ensuring that illegal forced displacement does not take place. The ICC has no case law on forced displacement or on the punishable preparatory act of ordering. Therefore, the investigation team construed its objective and subjective elements in light of criminal justice notions (i) punishable preparatory acts; (ii) 'ordering' as mode of individual criminal liability; (iii) effective control and command responsibility; and (iv) indirect perpetration as an organized structure of power. The team also analysed the concept of military necessity under Hague and Geneva Law (Olásolo et al. 2016).

The investigation highlights that the intention of the provision is to reduce civilian vulnerability to forced displacement during conflict. Responsibility cannot, therefore, be evaded by adopting indirect methods whose objective is achieved in the absence of a definitive 'order'. The investigation finds a number of authors interpret the provision in this way (Willms 2009). This interpretation is further strengthened by the preparatory works of AP II (1977) in which the expression 'forcible displacement' is used to include both indirect and direct methods of committing the crime.

The El Rosario Clinics' review of UN resolutions and sources of CIHL such as Rule 129 (B) of the ICRC [2005] CIHL study further establishes this position. The obligation, moreover, is underlined on parties to avoid causing displacement, e.g. through indiscriminate attacks. Those in a position of ordering, therefore, are responsible for conflict induced displacement whether it is intentional or not (Olásolo et al. 2016).

The preceding paragraphs have, by examining the research of the El Rosario International Law Clinic, found that those in a position to order are responsible for forced displacements. Furthermore, that those in a position to order are responsible whether direct or indirect methods are deliberately employed or if the forced displacement of civilians was intentional or not.

\section{Defining the act of 'ordering' forced displacement}

The following section continues the examination of the El Rosario International Law Clinics research with the objective of delineating the concept of ordering under IHL. Consequentially, the research of the El Rosario Clinic provides the criteria which an order of forced displacement/evacuation would need to fulfil to be considered legal.

The El Rosario International Law Clinic found two established positions regarding the definition of ordering as a criminal act. One position based on the broad intention of AP II (1977) Art. 17 found that; '(...) "ordering" should be interpreted as any voluntary action that causes the displacement' (Willms 2009 p558-559). Consequentially parties are responsible for acts which directly, or indirectly, cause the displacement of the civilian population. The second position based on the drafting process of the RS Article in question maintains that "ordering" is a preparatory act prohibited in itself and that other acts, such as instigating, may not be considered orders. Accordingly, under this position liability would only attach in the issuance of an order, regardless of whether the order leads to civilian displacement or not (Dörmann 2003 p431-407; Olásolo et al. 2016 p70-71).

The origin of RS Art 8(2) (e) (viii), however, can be traced back to AP II (1977) Art 17 and GC IV Art. 49 which indicate that direct and indirect acts which cause, or may cause displacement, are prohibited [ICRC 2005]. Conversely, the ICC statute definitions of individual criminal responsibility in RS Art 253 (a) and (b) suggests that, for the order to be a crime, forced displacement must at least be attempted. The order itself, therefore, may not be considered an independent crime, in that the criminal act ordered must take place or be attempted for liability to attach (Olásolo et al. 2016).

The El Rosario Clinic, however, found that this contradicted the fact that the provision itself must be interpreted strictly as RS Art 22 (2) states: 'The definition of a crime shall be strictly construed and shall not be extended by analogy. In case of ambiguity, the definition shall be interpreted in favour of the person being investigated, prosecuted, or convicted'. Furthermore, acknowledging the drafting of the RS, the omission of an order preventing forced displacement by superiors may be a crime in itself, and 'ordering the displacement of the civilian population' is specific in the provision.

Further analysis, by the International Law Clinic, brings to light that, 'ordering' if considered as a punishable preparatory act, must be consistent with other preparatory acts. The first, 'punishable preparatory act', which is contained in RS Art 25(3) (e), regards genocide and states: 'In respect of the crime of genocide, directly 
and publicly incites others to commit genocide'. Furthermore, the crime lay 'in (...) the instigator's intent to cause the required state of mind in a third party'. Cassese et al. (2013) holds that any preparatory act of ordering, that may lead to a crime provided for under the ICC Statute, is prohibited (Olásolo et al. 2016).

Subsequent to a further analysis of jurisprudence, and case law, the El Rosario Clinic found, the following elements constitute the war crime of 'ordering the displacement of civilians' in the Ntaganda case:

a. The person ordered a displacement of a civilian population.

b. Involved civilians' security or military necessity did not justify the order.

c. The person was in a position to effect displacement by giving an order.

d. The conduct took place in the context of and was associated with an armed, non-international conflict.

e. The person was aware of the factual circumstances surrounding the armed conflict (Ibid p77-78).

Here, requirement b. diverges somewhat from the findings of this research analysis which suggests that stakeholders might exclude military necessity as an exception unless it involves civilian security (Hayashi 2010). In relation to 'ordering' and requirement c. 'the person was in a position to effect displacement by giving an order', there are a number of subjective and objective elements that the International Law Clinic [2014] considered in its definition of 'ordering' including:

Besides the primary order, there may be a chain of orders and several levels of command.

Those responsible, e.g. may order a small or large force, be a military commander, a politician, or a business executive.

That command responsibility is inherent in ordering.

The organization that receives the order can carry it out.

Those that receive the order must have the authority to transmit it and/or the potential material perpetrators of the capacity to carry out the crime.

That there is sufficient hierarchical structure and fungibility that the order leads to action.

Planning to displace through issuing of instructions constitutes an order.

A person is aware of the substantial likelihood of displacement through their order.

The elements of crimes require that the person be in a position to effect such displacement by giving an order.

An omission in preventing an act, or the carrying out of an order, amounts to an order.
The research of the El Rosario International Law Clinic found the ICTY had established a position in CIHL through its definition of the provisions of GC IV Art. 49.

Finally, the International Law Clinic, after a comprehensive comparative study of legal theory, international Jurisprudence, and case law, found that 'a superior who issues a displacement order to incur criminal liability, it is necessary that such an order:

(i.) is issued in breach of the procedure established in Article 49 of GC VI [1949];

(ii.) does not state the temporal nature of the displacement; or

(iii.) is not followed by the return of the displaced civilian population to their homeland, once the circumstances that justified its displacement have disappeared' [Olásolo et al. 2016 p87].

This segment, which provides an examination of the research of the El Rosario International Law Clinic, has delineated the concept of ordering. In addition, this section through the research of the El Rosario Clinic has established the criteria of a legal order of forced displacement or evacuation.

\section{When forced displacement becomes pillage}

The following part of this research analysis aims to define under IHL when forced displacement becomes pillage or illegal appropriation. The aim is to provide criteria that stakeholders can apply to establish if through forced displacement, pillage, or illegal appropriation has been committed.

IHL requires that the party responsible for an eviction/legal forced displacement facilitates the voluntary return of the population to the location from where they were displaced, i.e. 'Persons thus evacuated shall be transferred back to their homes as soon as hostilities in the area in question have ceased' [GC IV Art 49 1949]. As this study has shown, through an examination of IHL treaties, and CIHL, an evacuation or legal displacement must be temporary and during the displacement the responsible party must make adequate provision for the welfare of the civilians. Without these conditions being fulfilled, therefore, an illegal act of transfer or forced displacement has taken place.

The motive of the forced displacement can be assessed, subsequently, in the unwillingness of parties to facilitate return. This paper proposes that once hostilities in an area which can endanger civilians have ceased, the responsible parties must facilitate return within a designated timeframe. Consequentially, therefore, if they do not facilitate return within the established timeframe, the responsible party would automatically be liable for 
prosecution for both forced displacement and pillage. The significance is that the timeframe places an obligation on the parties of the conflict to facilitate return. As a consequence, the difficult issue can be avoided of establishing if the displacement was legal, i.e. carried out due to military necessity for the security the civilian population (Zayas 1975).

Therefore, an illegal forced displacement has taken place: If the parties to a conflict do not facilitate voluntary return, within a specific timeframe, and once civilian security is not effected by military engagement between parties.

Logically, therefore, if conflict parties continue to control an area and do not facilitate return, profit from, or occupy the HLP of the civilians, then the property has been illegally appropriated, i.e. pillaged.

Therefore, in legal terms, stakeholders can establish when an act of unlawful displacement should include an additional charge of pillage, if they can establish the following;

a.) An indication that a criminal act of illegal dispossession and or pillage has occurred:

(i.) Is either in the failure to facilitate voluntary return, by the responsible party; or

(ii.) Omission of legal ordering that facilitates displacement (evacuation) and return.

b.) That an act of displacement might be considered pillage if both the following criteria are fulfilled:

(i.) Return is not facilitated; and

(ii.) If the parties possess and or profit from the HLP, from where civilians were displaced (Parties here being the internationally recognized parties in an armed conflict).

This section has completed the central objective of this paper which was to delineate IHL which can be applied to reduce civilian vulnerability to forced displacement and illegal appropriation through forced displacement. The section does not, however, define the scope of pillage as a crime or answer if forced displacement employed to dispossess can be considered pillage.

\section{Defining the crime of pillage}

The following section hopes to provide an accurate contemporary definition of the crime of pillage. Moreover, this penultimate part of the research analysis seeks to establish if HLP dispossession through forced displacement can be recognized as pillage. The section asks if civilian vulnerability can be reduced if illegal appropriation through forced displacement is recognized as pillage.

There has been renewed international interest in the crime of pillage, as a universal way to deter the illegal appropriation of civilian property, either public or private. A number of legal scholars argue for the reestablishment and simplification of the legal framework for the prosecution of pillage (Stewart 2011; Keenan 2014; Herik and Jong 2011). These scholars argue based on international jurisprudence, and the case law of the ad hoc international tribunals, that a simplified framework would allow the diverse forms of property theft to be prosecuted under one crime, pillage. Thereby, forced displacement employed to illegally appropriate civilian HLP would be prosecuted as pillage.

Numerous studies highlight the variety of HLP theft to which pillage applies to at macro, mezzo, and micro levels (Bangerter 2011; Maher 2015; Le Bilion 2001; McGregor 2009; Reno 2009a, 2009b; Kalyvas 2000; Engel and Ibáñez 2007). This is evident in natural resources pillage by corporate actors, usurpation of land by armed parties, and the theft of personal household items by individual combatants [ICC-01/04-02/06 p24; Prosecutor v. Brdanin 2004; The Prosecutor v. Charles Ghankay Taylor 2012]. A number of authors have highlighted that historically pillage by business has a long and clearly defined application under CIHL (Stewart 2011). At Nuremberg, for example, those prosecuted as war criminals included businessmen who engaged in natural resource pillage. Their crimes included the illegal appropriation of coal, oil, and precious metals from occupied territories such as France, Poland, and Russia. Those who were indirectly involved, furthermore, such as shareholders of banks that dealt in pillaged goods, were also prosecuted as war criminals [IMT 1945-46].

Examination confirms that pillage is included as a crime in the statutes of the ad hoc tribunals and other international courts, often under the synonyms of plunder, looting, and spoliation. It is generally accepted, nonetheless, that these terms are synonymous legally. Moreover, it is widely considered that they all relate to a wide definition of the varieties and forms of civilian property theft (Bing Bing 2002; Stewart 2011; Keenan 2014). The UN ICTY [2009], significantly, simply defined pillage as 'embracing all forms of unlawful appropriation of property in armed conflict for which individual criminal responsibility attaches under international law.' The Statute of the UN ICTY [2009] maintains individual criminal responsibility under CIHL, to be defined as 'A person who planned, instigated, ordered, committed or otherwise aided and abetted in the planning, preparation or execution of a crime (...)'. The ICRC (2006) Business and International Humanitarian Law guidance document highlights the criminal responsibility of all those involved in pillage through forced displacement. Previous research by various authors has found that pillage is aligned with theft in the domestic law of most countries (Herik and Jong 2011 et al.). Pillage has been recognized as a crime in 
legislation as early as the Lieber Code of 1863, which prohibited pillage or sacking under the penalty of death (Stewart 2011).

This analysis of IHL provisions, and CIHL, shows pillage is universally prohibited in IAC, and NIAC [HR 1907; GC 1949; Rome Statute 2002]. The ICRC CIHL Study Volume 1 Rule 52 underlines that 'State practice establishes this rule as a norm of customary international law applicable in both IAC and NIAC'. The universal prohibition of pillage is further confirmed through examination of GC IV Art 33 applicable in IAC and AP II (1977) Art 4(2) (g), applicable in NIAC.

In addition, 'pillaging a town or place, even when taken by assault' is prohibited through the provisions RS Art 8 War crimes2. (b) (xvi) applicable in IAC, and under RS Art 8.2(e) (v) applicable in NIAC. A number of authors bring to light that the reference to a 'town or a place' is not in line with IHL, and further, the prohibition of pillage is universal (Stewart 2011; Keenan 2014). Furthermore, AP II (1977) Art $4 \mathrm{~g}$ ) underlines that 'pillage is prohibited at any time and in any place whatsoever'. In relation to CIHL, the ICC in Prosecutor v. Germain Katanga [2014] found 'In the opinion of the Chamber, the pillaging of a town or place comprises all forms of appropriation, public or private, including not only organized and systematic appropriation, but also acts of appropriation committed by combatants in their own interest' [ICC-01/04-01/07- 3436 para 905].

Pillage through displacement can be established as a widespread and systematic policy, which directly targets civilians and civilian property. An examination of the case law of the JPT, ICTY, IMT, SCSL, and the ICC will dispel any assumption that forced displacement is simply an unavoidable consequence of military engagement [Prosecutor v. Bosco Ntaganda ICC-01/04-02/06; The Prosecutor v. Charles Ghankay Taylor SCSL-03-01-A; Prosecutor v. Brdanin IT-99-36-T; Prosecutor v. Radovan Karadžić IT-95-5/18-T para 2539]. It becomes increasingly clear, furthermore, that forced displacement is employed to commit pillage. Furthermore, as a review of state military manuals and ANSA combat codes, from numerous countries including, DRC, CAR, China, Philippines, and Colombia, can confirm, pillaging civilian property is generally prohibited by armed parties themselves (Bernard et al. 2011a, b).

This research analysis suggests that IHL prohibits the appropriation of civilian property by force by state or ASNAs. The majority of states, however, have attempted to reserve the right to appropriate civilian property through forced displacement, and this can be seen in state military manuals (ibid). It is important to acknowledge, furthermore, that as it appears under CIHL, parties to a conflict may, in certain circumstances, lawfully subject civilian property to military requirements, e.g. requisition for the needs of the army of occupation [ICRC Rule 51 2005].

Through this section, we have defined the crime of pillage. The finding is that pillage as a crime applies to any form of illegal appropriation of civilian property during conflict. Therefore, forced displacement employed to illegally appropriate civilian HLP during conflict may be considered pillage. Through this analysis, moreover, we can say that IHL, through pillage, provides considerable protection from dispossession through displacement.

\section{Pillage prohibiting appropriation of civilian property by force}

This final section examines pillage in relation to the prohibition of appropriating civilian property by force, under IHL. The final paragraphs of this research analysis aim to establish that appropriation of civilian property by force is categorically prohibited under IHL.

According to the following statement from the nonbinding ICC Elements of Crimes: 'As indicated by the use of the term "private or personal use", appropriations justified by military necessity cannot constitute the crime of pillaging' ICC [2010]. Significantly, a number of authors have examined the phrase 'personal or private use'. These authors find its use to be contradictory to, and not in line with, the rules of war, historical precedence, or current legal thought (Herik and Jong 2011; Stewart 2011). Stewart (2011 p20) found that '(...) military necessity cannot act as an independent and separate justification for pillage, as military necessity cannot act as a justification for a violation unless the term "military necessity" is explicitly listed as an exception to the rule in question. This is not the case for pillage, which is prohibited in absolute terms'. This is confirmed by GC IV Art 33, AP II (1977) Art 4 g), and RS Arts 82 (e) (v), and 82 (b) (xvi), none of which provide accommodation for 'pillage' due to military necessity. Significantly, under IHL treaties, there is no allowance for appropriation of civilian property by illegal force, i.e. pillage.

There seems to be, however, some accommodation made for appropriation of civilian property, due to military necessity under CIHL. ICRC CIHL Study Rule 51 allows for the appropriation of public property subject to the laws of usufruct and prohibits the confiscation of private property unless it is due to imperative military necessity. RS Art 82 (a) (iv) provides some allowance for requisition, due to military necessity. Even so it must be legal, as the provision prohibits the extensive, unlawful, or wanton appropriation of civilian property. A number of authors, conversely, maintain that appropriation by force can take place, but it cannot amount to resources of a 'sufficient monetary value', that would cause grave consequences for civilians (Stewart 2011). 
Significantly, however, an in-depth analysis suggests that this perspective fails to distinguish between CIHL and IHL treaties. As IHL treaties definitively prohibit appropriation of civilian property through illegal force, through the prohibition of pillage in GC IV Art 33, AP II (1977) Art 4 g), and also RS Art 82 (e) (v) and 82 (b) (xvi). In addition, the only allowance for legal appropriation of civilian property is found in RS Art 82 (a) (iv). This analysis has shown that allowances in CIHL for appropriation of civilian property due to imperative military necessity are extremely specific and do not, in any circumstances, justify pillage. We can maintain therefore that under IHL, pillage, or the appropriation of civilian property by illegal force is categorically prohibited.

The final passages of this research analysis highlight that legal appropriation of civilian property, whether through forced displacement any other act is categorically prohibited under IHL. Highlighting that through this research analysis, it has been established that there are no exceptions which enable parties to employ forced displacement to dispossess civilians of their HLP.

\section{Legal research analysis findings}

Forced displacement can be considered unjustifiable, illegitimate, and illegal, under IHL if:

i.) It cannot be proven, that the security of civilians is threatened, i.e. due to pending or actual military engagement

ii.) If a plan for return is not apparent and voluntary return is not facilitated (immediately once hostilities have ceased in the specific area in question)

iii.) If there is a breach of the procedure established in Article 49 of GC VI [1949]

iv.) If the protecting power (if one has been appointed) has not been informed that an evacuation is taking place

Pillage will be considered to have taken place if both:

i.) Voluntary return is not facilitated (e.g. immediately or within three months)

ii.) If parties possess and or profit from the HLP from where the civilians were displaced

\section{Conclusion}

In the context of displacement, it is vitally important for those who decide to return that there is a clear, unambiguous, and accessible written record available of what occurred, in the event that there is resistance to the return by those who were responsible for, or acquiesced in, or have benefited from the displacement (Korner 2012 p13).
The findings of this paper show that under IHL treaties, pillage is categorically and universally prohibited and can be considered to have taken place if civilian property is appropriated by illegal force through illegal forced displacement.

Regarding the point at which forced displacement becomes pillage, the time factor is significant in the findings. There is, for example, allowance for forced displacement due to civilian security or military necessity. Therefore, time to establish that a particular forced displacement is illegal is required. Nonetheless, if dispossession is the obvious intention, and the forced displacement is clearly illegal, then immediately establishing pillage may be possible. What if the crime is carried out extemporaneously, however, and the forced displacement was not obviously illegal? Consequentially, therefore, establishing the exact point at which displacement becomes pillage should be done from the moment at which military engagement that affects the security of civilians has ended. The first element is if voluntary return is not facilitated within a reasonable timescale contingent on the time required for return (e.g. 3 months). Thereafter, if parties occupy or profit from the HLP required by the civilians to survive or remain at origin, pillage can be considered to have taken place.

This paper has established a number of difficulties in addressing illegal forced displacement and pillage through displacement. Further, the findings provide guidelines based on IHL, which might enable common ground to be established between stakeholders. The risks involved for humanitarians, civilians, and other stakeholders engaging armed actors on such contentious issues cannot be overstated. Any proposed action, therefore, should be accompanied by complexity analysis or other contextual risk assessment method. This study suggests that there is, nevertheless, considerable protective value in stakeholders being facilitated with guidelines on illegal forced displacement and when it becomes pillage or illegal appropriation. Numerous frameworks and guidelines on forced displacement were reviewed during the research for this study, and none address the issues raised in this paper. Therefore, the following recommendations are aimed at humanitarian organizations and other stakeholders seeking to reduce civilian vulnerability illegal forced displacement and to dispossession through displacement.

\section{Recommendations}

This paper advocates four key activities:

1. Application of provisions based on the findings of this paper in binding agreements with armed parties: Provisions based on the findings of this paper might 
be included, for example, in peace agreements in IAC or ceasefire agreements in NIAC. This research analysis underlines that parties to NIAC are obliged through GC Common Article 3 to enter into special agreements and by CIHL to adhere to the criteria contained in GC IV Art 49. The work of the ICRC and Geneva Call suggests that the inclusion of relevant provisions in agreement documents provide a binding form of legal protection, which can immediately reduce civilian vulnerability to specific violations (Lacroix et al. 2011; Ruaudel 2013). Common agreement documents for application by stakeholders might be drafted, which are specific to or give particular attention to forced displacement and illegal appropriation through displacement (Mack and Pejic 2008). These documents might include, for example, a deed of commitment on forced displacement and HLP pillage (Personal Interview 2016). Recommended activities might include

(a) identifying the root causes and patterns of displacement through contextually relevant research;

(b) establishing key stakeholder relations identifying their needs, motives, and objectives; (c) continuous contextual risk analysis, including assessment of existing armed actor engagement, and threat to civilians or humanitarian staff; (d) stakeholder training in IHL/IHRL and the creation of unilateral, bilateral, and multilateral agreements; (e) the creation and adoption of special agreements with armed parties and key stakeholders; and (f) the establishment of monitoring, reporting, verification, and enforcement mechanisms.

2. Dissemination of IHL guidelines on forced displacement and illegal appropriation through forced displacement to key stakeholder groups: Contemporary research and the issues which this paper raises suggest that the humanitarian approach to forced displacement needs to be revaluated. The issues raised in this paper, if disseminated widely, may contribute to an improved approach to reducing civilian vulnerability to forced displacement. The existing guidebooks or manuals on forced displacement inadequately address the issues raised in this paper. The majority of publications on forced displacement from agencies such as the ICRC, UNHCR, IASC, and NRC, are concerned with the protection of IDPs, and refugees, post displacement. These publications and normative frameworks, in addition, contain numerous issues which constitute gaps for protection actors attempting to reduce vulnerability to the act of forced displacement. In the Handbook for the Protection of Internally Displaced Persons (PCWG
2007), for example, we see the following question: 'Is forcible displacement an offence that is prosecuted and are all actors aware that arbitrary displacement is unlawful?' This question contradicts itself as forcible displacement is not always an offence, as the phrase then implies by indicating that only arbitrary displacement is unlawful. Normative frameworks, furthermore, while providing important legal protection to IDPs and refugees, provide little assistance to protection actors trying to reduce vulnerability to forced displacement or HLP pillage through forced displacement. The Guiding Principles on Internal Displacement principle 6 (1) and the Pinheiro Principles 5 (1) use the term '(...) right to be protected against being arbitrarily displaced' without a clear explanation that indicates 'arbitrary' here implies when the exceptions of military necessity or civilian security are inapplicable. The principle objective of the recommended IHL guidelines would be to clarify in simple terms, for all stakeholders, when forced displacement is illegal and when forced displacement becomes illegal appropriation. The guidelines might contain, for example, a chapter aimed at armed parties including a section on the responsibility to evacuate civilians whose security is compromised by imperative military operations. In addition, include a section to provide instruction on how to carry out a legal evacuation/forced displacement (i.e. to agree host community support for IDPs, facilitate return, and to respect civilian objects). The guidelines, furthermore, should give clear instruction on 'ordering' and clarify who is responsible if forced displacements do take place.

3. Fast tracking of pre-emptive HLP registration processes in vulnerable 'at risk' of displacement communities: The fast tracking of HLP registration might be achieved through formal or customary registration systems, community participatory mapping, or other contextually relevant methods (Unruh 2014). A standard HLP registration document might be developed for communities 'at risk' of displacement. These documents might be stored individually, for example, online. Research suggests that without evidence of ownership or occupancy it is difficult to protect HLP from being illegally appropriated through forced displacement. Consider an individual IDP, for example, attempting to establish the right to return, dispute the illegal occupancy of their home post-conflict, or simply provide evidence that they have been displaced from HLP where they were legally present. If customary HLP practices are dominated by criminal, patriarchal, or ethno-centric power structures then informal 
participatory mapping may provide discrete evidence of legal presence. HLP mapping, however, can be a formidable undertaking especially in conflict contexts, where at-risk communities may have limited education and live in impoverished conditions. Nevertheless, the value of micro-level registration is that armed parties may be deterred from displacing civilians from HLP and they may have difficulty retaining or trading. HLP registration systems, furthermore, have their own significant protective capacity.

4. The development of Humanitarian Protection strategy with a focus on forced displacement and HLP pillage: This paper does not concern the design of humanitarian protection strategy to address forced displacement or HLP pillage. Furthermore, the research for this paper has established that, beyond engaging armed parties on their obligations under IHL, humanitarian experience in protecting civilians from illegal forced displacement or HLP pillage is limited (Zapater 2010). Therefore, this paper is appealing to protection specialists and humanitarian academics to research and develop humanitarian protection strategy on forced displacement which may be applied in the field. The research for this article suggests that protection practitioners may consider incorporating the following actions in humanitarian protection strategies on forced displacement and illegal appropriation through forced displacement:

(a) continuous contextual risk analysis with particular focus on stakeholder motives needs and objectives and increasing engagement with armed actors; (b) identify or carry out contextually relevant research or data collection to identify root causes and factors which deter forced displacement and HLP pillage; (c) conduct community protection meetings and mapping to identify community coping mechanisms, risk areas, local protection structures, and to reinforce deterrence factors; (d) facilitate HLP registration through formal systems or informal methods to provide documentary evidence of legal presence on HLP; and (e) engage with armed parties and other stakeholders on community protection issues, provide training in $\mathrm{IHL}$, and facilitate the creation of agreement documents on forced displacement and HLP pillage.

\section{Abbreviations}

ANSA: Armed non-state actor; AP: Additional protocol; Art: Article; CIL: Customary international law; EWER: Early warning early response; GC: Geneva Convention; HLP: Housing, land and property; HR: Hague Regulations; IAC: International armed conflict; ICC: International Criminal
Court; ICCPR: International Covenant on Civil and Political Rights; ICESCR: International Covenant on Economic, Social, and Cultural Rights; ICHL: International Criminal and Humanitarian Law; ICID: International Commission of Inquiry on Darfur; ICRC: International Committee of the Red Cross; ICTJ: International Centre for Transitional Justice; ICTY: International Criminal Tribunal for former Yugoslavia; IHL: International humanitarian law; IHRL: International human rights law; IMT: International Military Tribunal; JCE: Joint criminal enterprise; JPT: Justice and Peace Tribunal; NIAC: Non-international armed conflict; UDHR: Universal Declaration of Human Rights; UN: United Nations

\section{Acknowledgements}

This article is based on the legal section of the author's, Network on Humanitarian Action (NOHA), master thesis: 'Humanitarian Protection: Pre-empting Displacement Pillage through International Humanitarian Law'. It is important, therefore, to acknowledge the guidance received from the NOHA and in particular University College Dublin (UCD), Belfield, Dublin 4, Ireland.

In addition, it is important to recognize the expert supervision of Prof Héctor Olasolo, and the other members of the investigation team from the International Law Clinic of the University of the Rosary in Bogota, Calle 12C No. 6-25 - Bogotá D.C. Colombia. The team wrote the 2014 Memorial 'Content and scope of the punishable preparatory act of ordering an act of displacement under article (8)(2)(viii) of the Rome Statute' for the "Office of Public Council for Victims" (OPCV) of the International Criminal Court (ICC). The members of the investigation team were: Melissa Macher Reyes, Álvaro Pío Jaramillo García, Daniela Rodríguez Cuenca, Laura Daniela González Guerrero, María Paola Gaviria Orjuela, Kerrin Geoffrey Buck, Andrea Guadarrama, María Elvira Guerra Cujar, José Bernardo Restrepo, Juan Sebastián Tole Ramírez y William Andrés Benjumea de Lima. "CONTENIDO Y ALCANCE DEL CRIMEN DE GUERRA DE ORDENAR EL DESPLAZAMIENTO DE LA POBLACIÓN CIVIL CONFORME AL ARTÍCULO (8) (2) (E) (VIII) DEL ESTATUTO DE LA CORTE PENAL INTERNACIONAL", en Olasolo, H. (ed.), "Derecho Internacional Penal y Humanitario. Estudios de la Clínica Jurídica Internacional de la Universidad del Rosario (Colombia) y del Instituto Ibero-Americano de la Haya para la Paz, los Derechos Humanos y la Justicia Internacional (Holanda) en su V Aniversario" (Valencia (Spain): Tirant lo Blanch, University of El Rosario, Iberoamerican Institute of The Hague for Peace, Human Rights and International Justice, 2016), pp. 69-90.

\section{Authors' information}

Kerrin Geoffrey Buck MSc (Hons) has extensive experience in Humanitarian Action and has worked with displaced people in a number of complex emergency contexts including Former Yugoslavia (1993-1994), Angola (1998-1999), Colombia (2014-2015), and currently in South Sudan (2016).

\section{Competing interests}

The author declares that there are no competing interests.

Received: 22 June 2016 Accepted: 12 December 2016

Published online: 15 February 2017

\section{References}

ACLED (2015) Armed conflict location and event data project., http://www. acleddata.com/

Adhikari P (2013) Conflict-induced displacement, understanding the causes of flight. Am J Polit Sci 57:82-89, Midwest Political Science Association

Amnesty (2012) Universal jurisdiction a preliminary survey of legislation around the world - 2012 update. Amnesty International, United Kingdom

Andersen M (2011) The UN Principles on Housing and Property Restitution for Refugees and Displaced Persons (The Pinheiro Principles): suggestions for improved applicability. J Refug Stud 24(2):304-322, 10.1093/jrs/fer005. Published by Oxford University Press

Andreu-Guzmán F (2013) Criminal Justice and Forced Displacement: International and National Perspectives. International Centre for Transitional Justice: Research Unit. The Brooking Project on Internal Displacement, Switzerland

AP I (1977) Protocol Additional to the Geneva Conventions of 12 August 1949, and relating to the Protection of Victims of International Armed Conflicts (Protocol I), 8 June 1977 and commentaries of 1987 
AP II (1977) Protocol Additional to the Geneva Conventions of 12 August 1949, and relating to the Protection of Victims of Non-International Armed Conflicts (Protocol II), 8 June 1977 and commentaries of 1987

Attorney General v. Adolf Eichmann (Trial Judgement) Criminal Case No. 40/61 11 December 1961

Azam JP, Hoeffler A (2002) Violence against civilians in civil wars: looting or terror? J Peace Res 39(4):461-485. doi:10.1177/0022343302039004006

Ballintine K, Nitzschke H (2003) Beyond greed and grievance: policy lessons from studies in the political economy of armed conflict IPA policy report

Bangerter O (2011) Reasons why armed groups choose to respect international humanitarian law or not. Article, International Review of the Red Cross. 882: 353-384. doi:10.1017/S1816383111000385

Bernard (ed) et al (2011) Humanitarian debate: law policy action engaging armed groups. Int Rev Red Cross 93: 883

Bernard (ed) et al (2011) Humanitarian debate: law policy action understanding armed groups and the applicable law. Int Rev Red Cross 93: 882.

Bing Bing J (2002) "Protected property" and its protection in international humanitarian law. Leiden Journal of International Law 15:131-153, Cambridge University Press

Bongard P, Somer J (2011) Monitoring armed non-state actor compliance with humanitarian norms: a look at international mechanisms and the Geneva Call Deed of Commitment. Int Rev Red Cross 93:883, 673-706, 10.1017/ S1816383112000197

Bradley M (2013) Refugee repatriation: justice, responsibility and redress. Cambridge University Press, United Kingdom

Cantor D (2012) Does IHL prohibit the forced displacement of civilians during war? Int J Refugee Law 24(4):840-846, Published by Oxford University Press, United Kingdom

Cassese A, Gaeta P, Baig L, Fan M, Gosnel C (2013) Cassese's International Criminal Law. Oxford University Press, Global

Dörmann K (2003) Elements of war crimes under the Rome Statute of the International Criminal Court. International Committee of the Red Cross. Cambridge University Press, United Kingdom

Engel S, Ibáñez A (2007) Displacement due to violence in Colombia: a household-level analysis: economic development and cultural change. Vol. 55, No. 2. The University of Chicago Press; United States, pp. 335-365

GC IV (1949) Convention (IV) relative to the Protection of Civilian Persons in Time of War. Geneva, 12 August 1949 and Commentary of 1958

Golay C, Cismas I (2010) Legal opinion: the right to property from a human rights perspective. Rights and Democracy. International Centre for Human Rights and Economic Development. Geneva Academy, Switzerland

Hayashi N (2010) Requirements of military necessity in international humanitarian law and international criminal law. Boston Univ Int Law J 28(39):39-140

Heffes E, Kotlik M (2014) Special agreements as a means of enhancing compliance with $\mathrm{IHL}$ in non-international armed conflicts: an inquiry into the governing legal regime. 96 (895/896) Generating respect for the law. Int Rev Red Cross 1195-1224

Henckaert J, Doswald-Beck L (2005) Customary international humanitarian law volume I: rules. 2005. Cambridge University press, Cambridge

Henckaerts J (2010) Customary international humanitarian law: taking stock of the ICRC study. Nordic J Int Law 78(2010):435-468, journal of international law. Martinus Nijhoff Publishers

Herik L, Jong D (2011) Revitalizing the Antique war crime of pillage: the potential and pitfalls of using international criminal law to address illegal resource exploitation during armed conflict. Crim Law Forum 22(3):237-273

HR (1907) Convention (IV) respecting the laws and customs of war on land and its annex: regulations concerning the laws and customs of war on land. The Hague, 18 October 1907

ICC (2010) Elements of crimes. International Criminal Court.ICC

ICCPR (1966) International Covenant on Civil and Political Rights.999 UNTS 171

ICESCR (1954) International Covenant on Economic, Social and Cultural Rights GA/RES/2200A (XXI)

ICID (2004) Report of the International Commission of Inquiry on Darfur to the United Nations Secretary-General

ICJ (1945) Statute of the International Court of Justice

ICRC (2006) Business and International Humanitarian Law. An Introduction to the rights and obligations of Business Enterprises under International Humanitarian Law. International Committee of the Red Cross, Switzerland

ICRC (2013) Professional Standards for Protection Work carried out by humanitarian and human rights actors in armed conflict and other situations of violence. International Committee of the Red Cross, Switzerland
ICTJ Research Unit (2012) Transitional justice and displacement: challenges and recommendations. Brookings-LSE Project on Internal Displacement

ICTY (2009) Updated Statute of the International Criminal Tribunal of the Former Yugoslavia

IJRC (2016) International Justice Resource Centre. Universal jurisdiction. Website: http://www.ijrcenter.org/cases-before-national-courts/domestic-exercise-ofuniversal-jurisdiction

Jacques M (2012) Armed conflict and displacement: the protection of refugees and displaced persons under IHL. Cambridge University Press, UK

Jong D (2015) Armed opposition groups and the right to exercise control over public natural resources: a legal analysis of the cases of Libya and Syria. Neth Int Law Rev 62:3-24. doi:10.1007/s40802-015-0007-0

Kalyvas S (2000) The logic of violence in civil war. Cambridge University Press, United Kingdom

Keenan P (2014) Conflict minerals and the law of pillage. Chicago J Int Law 14(2):524-558, Article 6

Korner J (2012) Criminal justice and forced displacement in the former Yugoslavia. Case Studies on Transitional Justice and Displacement. Project on Internal Displacement. International Centre for Transitional Justice. Brookings-LSE, United Kingdom

Lacroix P, Bongard P, Rush C (2011) Engaging armed non-state actors in mechanisms for protection. Forced Migration Review 37

Lane $L$ (2016) Mitigating humanitarian crises during non-international armed conflicts - the role of human rights and ceasefire agreements. J Int Hum Action 1:2. doi:10.1186/s41018-016-0002-z

Le Bilion P (2001) The political ecology of war: natural resources and armed conflict. Polit Geogr 20(5):561-584

Leaning J (2011) Enforced displacement of civilian populations in war: a potential new element in crimes against humanity. Int Crim Law Rev 11:445-462, Martinus Nijhoff Publishers

Leckie S, Huggins C (2011) Conflict and housing land and property rights. A handbook on issues frameworks and solutions. Cambridge University Press, United Kingdom

Mack M, Pejic J (2008) Increasing respect for international humanitarian law in non-international armed conflicts. International Committee of the Red Cross, Switzerland

Maher D (2015) The fatal attraction of civil war economies: foreign direct investment and political violence, a case study of Colombia. Int Stud Rev 17:217-248

McGregor M (2009) Corporate impunity; how to really curb the pillaging of natural resources. Inter-American Development Bank, Washington, United States. Case W Res J Int Law 42(1):469-497

Merriam J (2016) Journal of International Law Stockton Centre for the Study of International Law, US Naval War College. Va J Int Law 83:146

Mulvey A (2013) The displaced claiming their rights in fragile states. Forced Migr Rev 43:29-31

Olásolo H (2013) Tratado de Autoría y Participación en Derecho Internacional Penal. Tirant lo Blanch

Olásolo H, Caballero L, Cabrales A, Fonseca C, Quijano L, Suárez D (2016) Derecho Internacional Penal y Humanitario. Tirant lo Blanch

Paglione G (2008) Individual property restitution: from Deng to Pinheiro and the challenges ahead. Int J Refugee Law 20(3):391-412. doi:10.1093/ijrl/een023

Personal Interview (2014) Court of Justice and Peace Bogota Colombia Personal Interview (2016) Pascal Bongard of Geneva Call (skype call)

Philippe $X$ (2006) The principles of universal jurisdiction and complementarity. Volume 88 Number 862 June 2006. Int Rev Red Cross

Philippe X (2008) Sanctions for violations of international humanitarian law: the problem of the division of competences between national authorities and between national and international authorities. Int Rev Red Cross 90:870

Prosecutor v. Charles Ghankay Taylor (Trial Judgement) SCSL- 03-01-T April 2012

Prosecutor v. Radosla v Brdanin (Trial Judgement) IT-99-36-T.ICTY. 1 September 2004

Prosecutor v. Radovan Karadžic (public redacted version of judgement issued on Volume I of IV)24 march 2016 IT-95-5/18-T para 2539

Reno W (2009) Explaining patterns of violence in collapsed states, contemporary security policy. Routledge. 30(2): 356-374. doi:10.1080/ 13523260903060250

Reno W (2009) Understanding criminality in West African conflicts, international peacekeeping. Routledge. 16(1): 47-61. DOI: 10.1080/13533310802485542

Roht-Arriaza N (2001) The Pinochet Precedence and Universal Jurisdiction. New England Law Rev. 311

Rome Statute (2002) The Statute of the International Criminal Court, ISBN No. 92-9227-227-6 
Rondeau S (2011) Participation of armed groups in the development of the law applicable to armed conflicts. Int Comm Red Cross 93:883

Ruaudel H (2013) Armed non-state actors and displacement in armed conflict. Produced by Geneva Call with the generous support of the Swiss Federal Department of Foreign Affairs. Geneva Call

Sassòli M (2010) Taking armed groups seriously: ways to improve their compliance with international humanitarian law. J Int Hum Law Stud 1:5-51

Schrepfer N (2012) Addressing internal displacement through national laws and policies: a plea for a promising means of protection. Int J Refugee Law 24(4):667-691

Seils P (2016) Handbook on complementarity: an introduction to the role of national courts and the ICC in prosecuting international crimes. International Centre for Transitional Justice, Switzerland

Stewart J (2011) Corporate war crimes: prosecuting the pillage of natural resources. Open Society Foundation. Open Society Institute, United Kingdom

The Prosecutor v. Bosco Ntaganda (Pre-Trial Chamber II) ICC-01/04-02/06. 9 June 2014

The Prosecutor v. Charles Ghankay Taylor (Appeals Chamber Judgement) SCSL-03-01-A. 26 September 2013

The Prosecutor v. Germain Katanga (Judgment pursuant to article 74 of the Statute)ICC-01/04-01/07. 7 March 2014

Tripathi S (2005) International Regulation of Multinational Corporations. Oxf Dev Stud 33(1):117-131

UDHR (1948) The universal Declaration of Human Rights. UNGA Res 217 A(III)

UN ICTY (2009) Updated statute of the International Criminal tribunal for the former Yugoslavia

United States v. Wilhelm List, et al (1948) P 1296. "Opinion and Judgment of Military Tribunal V,"

Unruh J (2014) Evidencing the restitution landscape: pre-emptive and advance techniques for war-torn land and property rights reacquisition., www.elsevier. com/locate/landusepol

UNSC (2004) Resolution 1564 S/RES/1564

VDC (2015) Violations documentation centre in Syria-special report on counterterrorism law no. 19 and the counter-terrorism court in Syria. CounterTerrorism Court: a Tool for War Crimes. VDC, Syria

Willms J (2009) Without order, anything goes? The prohibition of forced displacement in non-international armed conflict. International Review of the Red Cross 91(875):547-565

Zapater J (2010) Prevention of forced displacement: the inconsistencies of a concept. United Nations High Commissioner of Refugees, Switzerland

Zayas M (1975) International Law and Mass Population Transfers. Harv Int'l. L. J. $207-258$

\section{Submit your manuscript to a SpringerOpen ${ }^{\circ}$ journal and benefit from:}

- Convenient online submission

- Rigorous peer review

- Immediate publication on acceptance

- Open access: articles freely available online

- High visibility within the field

- Retaining the copyright to your article

Submit your next manuscript at $\gg$ springeropen.com 